\title{
Apuntes sobre El diario íntimo de Maliki 4 ojos, de la sin par Marcela Trujillo ${ }^{1}$
}

\section{Notes about El diario íntimo de Maliki 4 ojos, Written by the Unique Marcela Trujillo}

\author{
Rodrigo Cánovas \\ Pontificia Universidad Católica de Chile, Facultad de Letras. \\ Santiago, Chile. \\ rcanovas@uc.cl
}

\section{Resumen}

Este artículo es un análisis del cómic El Diario íntimo de Maliki 4 ojos (2011), de la pintora chilena Marcela Trujillo. Primero, hacemos un comentario de las formas gráficas de este cómic y de cómo se genera el personaje de Maliki, alter ego de la autora. Y luego, analizamos los roles que este personaje asume en el ámbito de la familia, la mujer, la sexualidad, el arte, la cultura y la política. Concluimos que en este cómic se parodian los estereotipos culturales de la mujer inscrita en la sociedad chilena.

Palabras clave: Maliki, cómic, diario de vida, mujer chilena.

\section{Abstract}

This article is an analysis of El Diario intimo de Maliki 4 ojos (2011), a comic written by the Chilean painter Marcela Trujillo. First we make a comment on the graphic forms and how the character Maliki -the author's alter ego- is created. Then, we study Maliki's roles in the areas of family, women, sexuality, art, culture and politics. We conclude that in this comic the Chilean women cultural stereotypes are exposed in a parodic expression.

Keywords: Maliki, comic, diary, chilean women.

1 Este trabajo forma parte del proyecto FONDECYT N¹130002 "Relatos (auto)biográficos chilenos (1991-2011): nuevas $\mathrm{y}$ antiguas señas de identidad”, del cual soy Investigador Responsable. 
Los textos autobiográficos adquieren gran visibilidad en Chile en el inicio de este siglo XXI, y se incluyen en la serie de relatos que responden la interrogante centrada en la comunidad política (las utopías de cambio social) desde la primera persona. Así, instauran una nueva utopía -la del yo-, que se superpone a la antigua, la desplaza o la reconfigura desde el juego de la autorrepresentación. Es el giro subjetivo de la construcción del mundo, la fractura del mundo entero por una mirada que lo llena de hoyos, sin llegar del todo a abolirlo. ${ }^{2}$

De las varias modalidades de las denominadas escrituras del yo (memorias, autobiografías, diarios íntimos, relatos de viaje, novelas autobiográficas, autoficciones y otras), nos interesa explorar el cómic. ${ }^{3}$ Para ello, hemos acudido a uno de los textos realizados por la artista visual Marcela Trujillo en el ámbito del cómic autobiográfico, El diario íntimo de Maliki 4 ojos (2011), cuyo análisis nos permitirá indagar sobre nuevas figuraciones del yo y del lenguaje en el contexto de los discursos actuales sobre la mujer, sus derechos ciudadanos y sexuales, y sus prácticas artísticas. ${ }^{4}$

\section{Jugando a componer un diario ilustrado}

Este texto de Marcela Trujillo se presenta como una autografía: la autora se dibuja como Maliki -con dos ampolletitas en su cabeza, a manera de pequeñas orejas, generalmente con una cara más de niña diablilla que de mujer-, quien nos cuenta de modo histriónicamente hilarante su vida emocional. ${ }^{5}$ Como ayuda a los lectores para que se sintonicen con los problemas existenciales de la protagonista (alter ego de la autora, su personaje creado), se anota: "mujer cuarentona, soltera, rellenita, morena, madre de dos niñitas, pintora, dibujante y profe santiaguina, que no logra bajar de peso, encontrar a su príncipe azul, ni ahorrar dinero" (s/p).

2 El llamado giro subjetivo se conecta con la revaloración de la primera persona como punto de vista en la generación del conocimiento en las ciencias humanas. En palabras de Beatriz Sarlo: "Se ha restaurado la razón del sujeto, que fue, hace décadas, mera 'ideología' o 'falsa conciencia', es decir, discurso que encubría ese depósito oscuro de impulsos o mandatos que el sujeto necesariamente ignoraba" (21).

3 Cómic: "A medium narrating its stories through images, words, and sequence. As a medium, comics have a particular set of technologies devoted to their creation and distribution, and a particular set of institutions, such as publishing houses and sales venues, which have developed around them. Formats of the comic medium are comic strips, comic books, the graphic novel, and web comics" (Kukkonem 169).

4 Marcela Trujillo (1969, Santiago de Chile) es una conocida artista visual, pintora e historietista, que ha incursionado en el arte figurativo y el neopop. Se formó en la Universidad de Chile (es Licenciada en Artes Plásticas) y luego realizó estudios de pintura en la Arts Studio League en Manhattan. Su personaje Maliki aparece primero en una historieta dispuesta en pequeñas tiras en el semanario chileno The Clinic en los años 2002 y 2003, más adelante compiladas en un libro titulado Las crónicas de Maliki 4 ojos (2010). A esta publicación le siguen cuatro libros, el último -Quiero ser flaca y feliz (2015) - en coautoría con la sicóloga Karolina Lama, en un guiño hacia los textos de autoayuda.

5 Autografía: "A term for the self-drawn autobiographical comics. Not only do these comics tell a story about the authors themselves, but they are also created in every aspect (words, images, lettering, etc.) as a personal expression of the authors" (Kukkonem 168). Hemos acuñado este término, pues nos parece adecuado para los textos de Maliki. Apuntemos de inmediato que la historieta gráfica tiene una gran plasticidad, adoptando y modificando creativamente formas venidas de la literatura y sus géneros afines como la crónica, el diario de vida y los relatos de viaje -cf. Trabado 26-27-. 
Ahora bien, en la escena autobiográfica se elige el formato del diario de vida, que la autora había practicado cuando niña (diario con un candado para que nadie lo pueda leer) y que siguió practicando, a sugerencia de un sicólogo, cuando joven. Así descubrió sus efectos terapéuticos: se miran los hechos pasados con otros ojos -se logra una comprensión en segundo grado, una toma de conciencia-. ${ }^{6}$ Este diario de juventud está guardado bajo cuatro llaves en la casa de sus padres. En cambio, sí tendremos acceso a un cómic escrito como si fuera un diario íntimo para ser compartido ad ovo: lo privado transpuesto a la escena pública, publicado.

¿Cómo se puede escribir una historieta ilustrada que sea un diario íntimo? Una de las singularidades de este texto es que tanto en su introducción como en su epílogo nos informa impúdicamente de la intimidad de su taller de creación, en la medida en que exhibe las reglas de producción material y edición de su obra, con lo que hace visible sus decisiones retóricas y enfatiza el trabajo de equipo que sostiene su libro.

Describamos el inicio, denominado "La Intro" (fig. 1). Primero, desde el encabezado ("Querido diario"), el diseño de la página y los tipos de letra, entendemos que se imita un diario, un diario de una comiquera. Un dibujito ingenuamente impúdico de Maliki en posición de loto, meditando en su creación, así lo corrobora. Y también, leyendo la página, nos informamos de su contacto con una diseñadora, el plan que realizan en conjunto y de la reunión que tienen con la editora. Conste que las involucradas aparecen con sus nombres y también se menciona el nombre de la editorial, lo que enuncia cierta función documental del texto.

Comentemos de inmediato que a diferencia de los cómics tradicionales, especialmente norteamericanos, adscritos a una producción en serie y ligados a empresas editoriales del rubro, este texto sigue una línea de carácter más bien artesanal y experimental, pues la autora presenta su proyecto a una casa editorial ajena a los cómics y elige a su diseñadora por un mensaje de Facebook (la web, amplia red de relaciones casuales). Así privilegia el tipo de intercambio mercantil que se le propone: canje (juego que sustituye la definición del dinero como capital, desplazándose con ello la noción de plusvalía). ${ }^{7}$

Esta primera página aclara las decisiones tomadas para la escritura de todo el cómic. Leamos:

6 Recordemos aquí la temprana (y capital) reflexión de Georges Gusdorf sobre el material autobiográfico: "es uno de los medios de conocimiento de uno mismo, gracias a la reconstitución y al desciframiento de una vida en su conjunto... La autobiografía es una segunda lectura de la experiencia, y más verdadera que la primera, puesto que es toma de conciencia: en lo inmediatez de lo vivido, me envuelve generalmente el dinamismo de la situación, impidiéndome ver el todo" (13).

7 Actualmente en Chile, la industria del cómic es de nicho, es decir, pequeña, pero con gran potencialidad de crecimiento. Este mercado ha aprovechado las oportunidades que brinda el internet para dar a conocer sus trabajos tanto por redes sociales como por medios especializados en la temática, como es el caso del sitio web Ergocomic. $\mathrm{cl}$, medio dedicado exclusivamente a la difusión de este tipo de obras y eventos relacionados al tópico. 
FIGURA 1

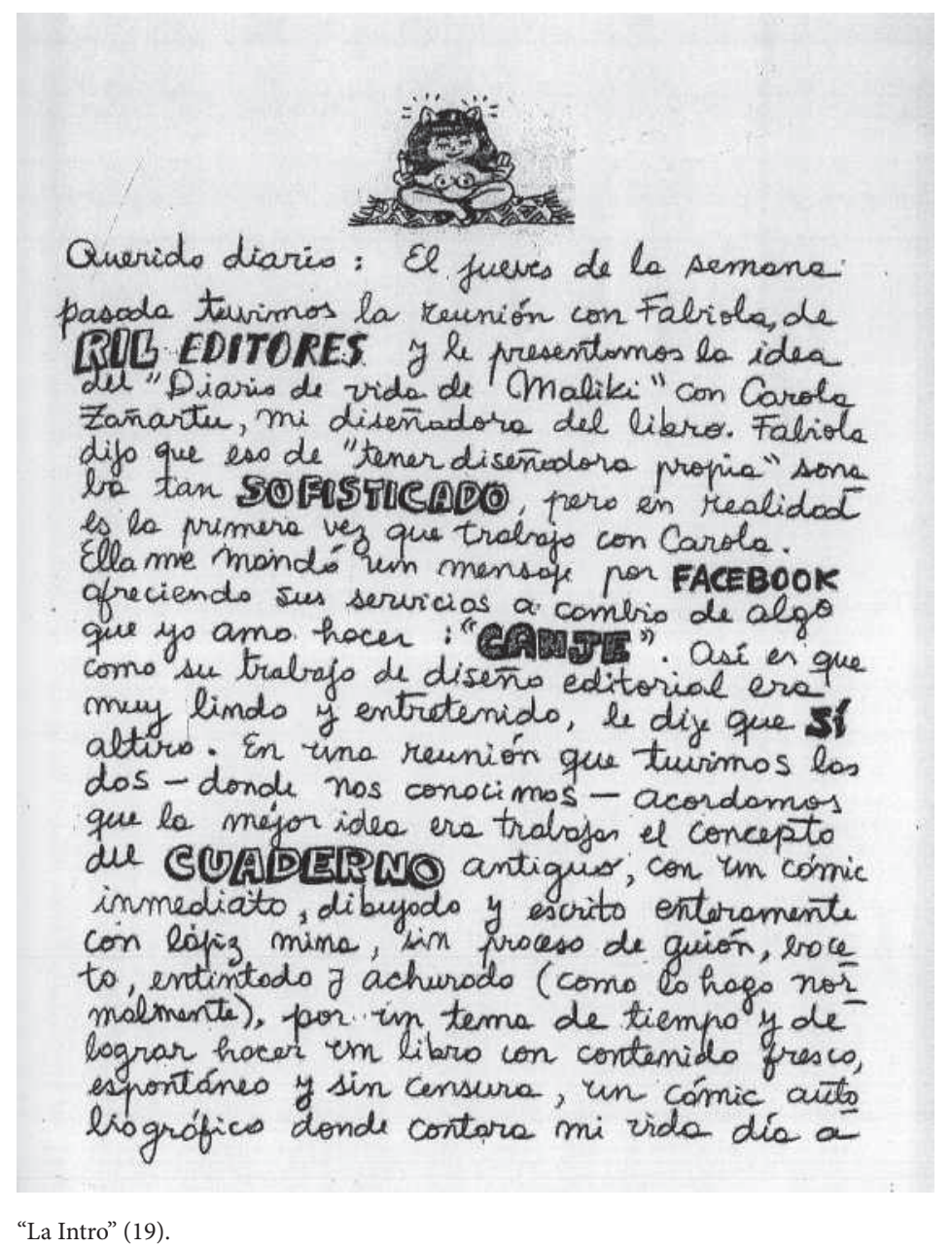

En una reunión que tuvimos las dos -donde nos conocimos- acordamos que la mejor idea era trabajar el concepto de Cuaderno antiguo, como un cómic inmediato, dibujado y escrito enteramente con lápiz mina, sin proceso de guion, boceto, entintado y achurado (como lo hago normalmente), por un tema de tiempo y de lograr hacer un libro con contenido fresco, espontáneo y sin censura, un cómic autobiográfico donde contara mi vida día a día como un 'Diario de vida' (Trujillo 19-20).

El formato elegido es el de un cuaderno antiguo, al que le corresponde la letra manuscrita del diario íntimo.

No olvidemos que en este ejercicio la letra se ciñe al espíritu de los tipos de letras ensayados en los cómics, definidos por su tamaño, grosor, inclinación y subrayado, 
que enfatizan la función emocional del lenguaje y que provocan en el lector todo tipo de sensaciones (ópticas, acústicas, táctiles). ${ }^{8}$

Una composición que nos evoca la premisa aristotélica del hacer versos como se hacen barcos, al reafirmar la manufactura de un artefacto, más allá del llamado de las musas. Trabajo alegre y cotidiano, que concibe la creación como un trabajo de equipo, donde hay distintos actores para cada función.

Copiemos la página de inicio del "Epílogo", que complementa el rasgo metalingüístico de este texto gráfico (fig. 2).

Querido Diario: Se me acabó el tiempo. La próxima semana debo entregar TODo mi diario a Carola, mi diseñadora (Bueno, no es 'MÍA', pero al menos ya somos amigas), corregido y escaneado para que ella lo arme y lo deje 'PICHOCALUGA' PARA entregarlo a Fabiola, mi editora (...todavía no salgo a celebrar con ella) y comencemos a revisar las pruebas de imprenta (algo así como las últimas ECOGRAFÍAs del feto antes de que pase a BEBÉ). Pero antes, el próximo fin de semana, tenemos la sesión de FOTo para la PORTADA con Ceci Plastivida Y CRISTIAN SOTO (141).

Yo escribo que escribo, yo dibujo que dibujo. Se nos exhiben aquí los instrumentos de la creación: un tipo especial de lápiz y una goma marca Pentel, más la tablilla con una hoja pegada a ella por adhesivos en sus cuatro costados. Ahora bien, como se hace durante todo este texto ilustrado, la escritura aparece modelada por distintos tipos de letra, lo que desencadena en el lector una serie simultánea de sensaciones que lo acercan empáticamente a la protagonista.

Poniendo atención al mensaje -escrito como si se estuviera entregando un artículo para un diario matutino justo en el límite del tiempo de entrega-, visualizamos el libro recompuesto en su cadena de producción y circulación, a saber: producción, escaneo, pruebas de imprenta, portada. Y además, los actores aparecen religados por relaciones afectivas que permite que este cómic amplíe la familia artística en que la autora está inserta: AMIGAS (y también amigos) y no simplemente clientes -lo cual lleva a la autora a compartir dieta con la diseñadora, canjear pintura por foto de Morrisey con su amigo fotógrafo responsable de la portada y salir a celebrar con su editora-.

Junto con visibilizar las condiciones de producción de su texto, la autoría también exhibe sus motivaciones valóricas y emocionales. La elección de confeccionar una publicación bajo la nomenclatura del diario íntimo, que compendia las intimidades de Maliki, constituye una abierta parodia al código de pudor y de la vergüenza ajena, y opera en la autora como una reafirmación identitaria de un yo necesitado de histrionismo para decir su verdad: "Muchas personas me han preguntado por qué

8 Para una introducción didáctica para la lectura de los cómics y una ejemplificación de sus recursos tipográficos, remitimos a la tesina de licenciatura de Ana Cecilia Osorio "Hacia una lectura semiótica de los recursos tipográficos en el cómic Mafalda". 


\section{FIGURA 2}

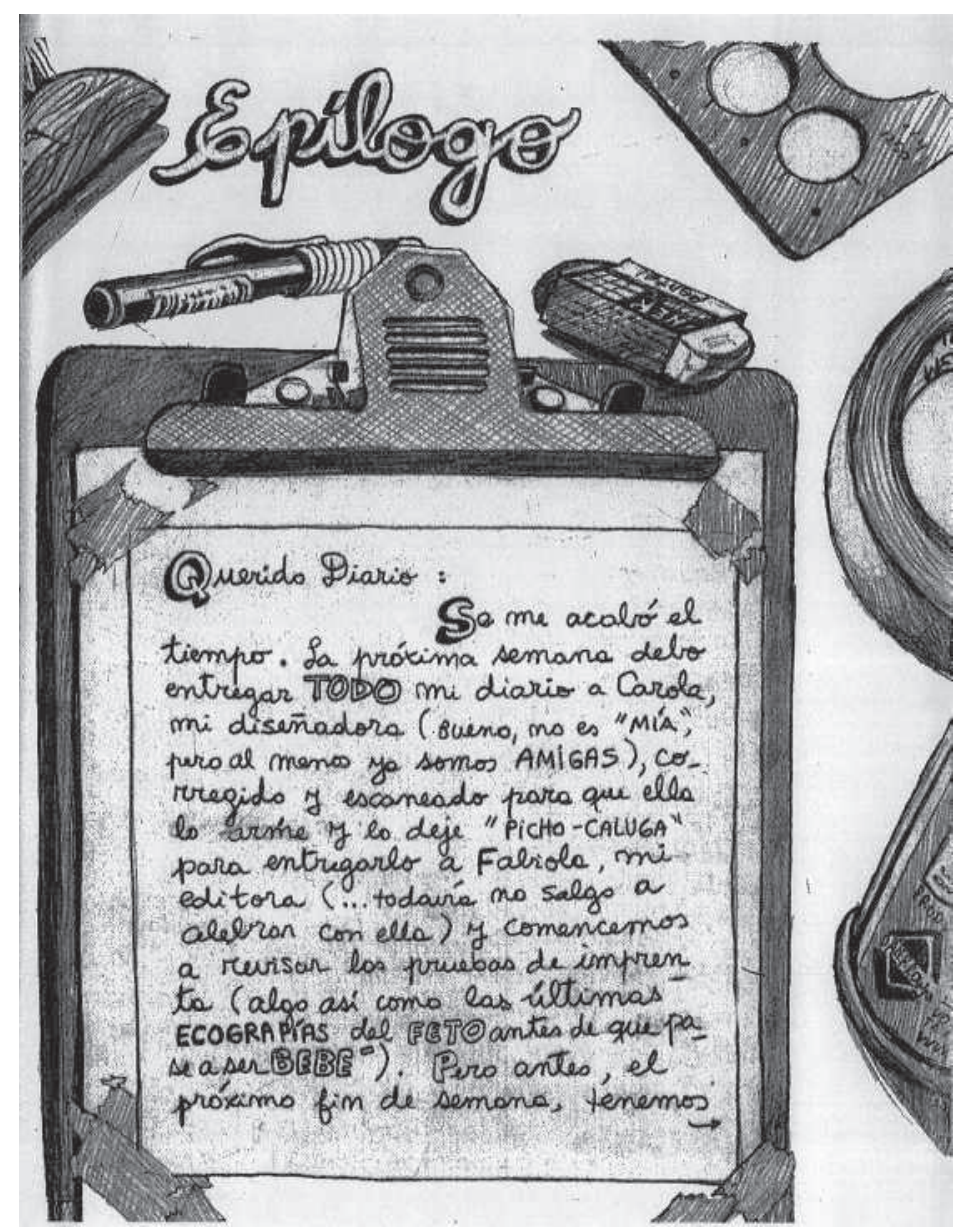

"Epílogo" (141).

EXPONGO mis intimidades sin PUDOR, si no me da 'VERGÜENZA' hacerlo, qué me pasa cuando decido COMPARTIR cosas que nadie HABLA porque se supone que hay que tener cierta... pRIVACIDAD, guardar ciertas PROPORCIONES, y todo para tener INTEGRIDAD, y decencia" (24-5). ${ }^{9}$ Recordemos que esta cita es un pálido reflejo del original, en cuanto no respeta sus distintos tipos de letras, cuya función es reforzar el

9 Según Sylvia Molloy, dentro de la tradición autobiográfica hispanoamericana, es normal la autocensura; a tal punto que las transgresiones tienen su lugar natural en los actos y confesiones de los personajes de ficción en cuentos y novelas. Por su parte, refiriéndose a los autobiógrafos y memorialistas chilenos del siglo xix y de la mitad del siglo $\mathrm{xx}$, Lorena Amaro considera que la regla es el decoro, ligado al miedo que muestra la élite a ser juzgada. En la actualidad, en las generaciones más recientes, la situación parece ser la inversa, como lo revelan en el caso chileno los textos autobiográficos de Roberto Brodsky, Pilar Donoso, Rafael Gumucio y Alberto Fuguet, entre otros. Y por supuesto, los cómics de Maliki, en franca polémica con la tradición del culto a la apariencia. 
diálogo paródico, mediante la provocación sensorial depositada en ciertas palabras claves de la cadena significante.

\section{Maliki atribulada. Un sico-cómic humorístico}

¿De qué trata esta historieta? De la vida sentimental de Maliki, gordita alter ego de la autora. Y ligado a ello, del oficio de artista (en especial, dibujante), del grupo familiar y del ejercicio de la ciudadanía, en calidad de mujer.

Iremos presentando esta historieta desde sus variadas enunciaciones gráficas. Lo que primero llama la atención es la desbordada combinatoria de lenguajes que convergen de modo recargado en cada página, y que sobresaturan el espacio y la capacidad de atención del lector -en realidad, un oyente visual, pues las letras les explotan en sus oídos, compitiendo con las imágenes-. Es común que la escritura del diario (confesión íntima) sea actuada seguidamente en la misma página por un cómic que no aparece encuadrado, o que aparezcan mezclados dibujos y reflexiones, en un dinamismo frenético que obliga a que leamos todo (con todo) simultáneamente. ${ }^{10}$

La autora dibuja la vida de Maliki desde su perspectiva como una mujer heterosexual. Maliki ha caído, según su expresión, en un hoyo negro, producto de su separación matrimonial. Se entusiasmó con su pareja, quedó embarazada casi de inmediato, casóse, parió dos hijas y a continuación -y aquí usamos el presente histórico-, se sigue enfriando la relación, ocurre la separación, Maliki quiere volver, pero su exmarido ya tiene a otra. Resultado: sexofobia. Para ponernos a tono con la animación ilustrada, copiemos la primera parte de esta trama (fig. 3).

Además de destacar la síntesis extrema que se hace de todo un capítulo amoroso; hay que enfatizar el modo singular de su composición grotesca y festiva. Los dibujos están inscritos en unas redondelas que están conectadas a través de una manguera, conformando una historia ya vivida y conocida, al modo de los culebrones (o teleseries). Una sintaxis que remite a un círculo vital, al modo de las imágenes de una ecografía de un feto (recordemos que en el epílogo se equiparan los avances del libro con las ecografía de un futuro bebé); un conjunto de dibujos que semejan probetas de laboratorio interconectadas, tetas o sostenes amarrados en serie o, incluso (en

10 Si cualquier cómic tiene la potencialidad de ser leído tabularmente -es decir, en todas las direcciones-, en la historieta de Maliki la lectura tabular se instaura como ley del relato; más aún, teniendo en cuenta que el cómic (imágenes, globitos y cajas narrativas autoriales) aparece mezclado (hibridizado) con los párrafos que conforman el supuesto diario íntimo. Para una reflexión sobre el cómic como una construcción híbrida (en términos de Mikhail Bakhtin) y sobre las lecturas que lo articulan, consúltese la tesis doctoral de Rain Newcomb "(In)Between Word and Image: Reading Comics" (2011). Refiriéndose a la lectura tabular, que pone en juego fuerzas centrípetas y centrífugas del lenguaje de modo simultáneo, la explica así: "To read tabularly means to read the whole spread at once. The reader starts by seeing the panels scattered across the page. There are an infinite number of possible relationships between the panels. In this way, tabular reading can begin with a recognition of the centrifugal forces of languages at work. But almost immediately, the centripetal forces of language reassert themselves and the panels link up" (64-5). 
FIGURA 3

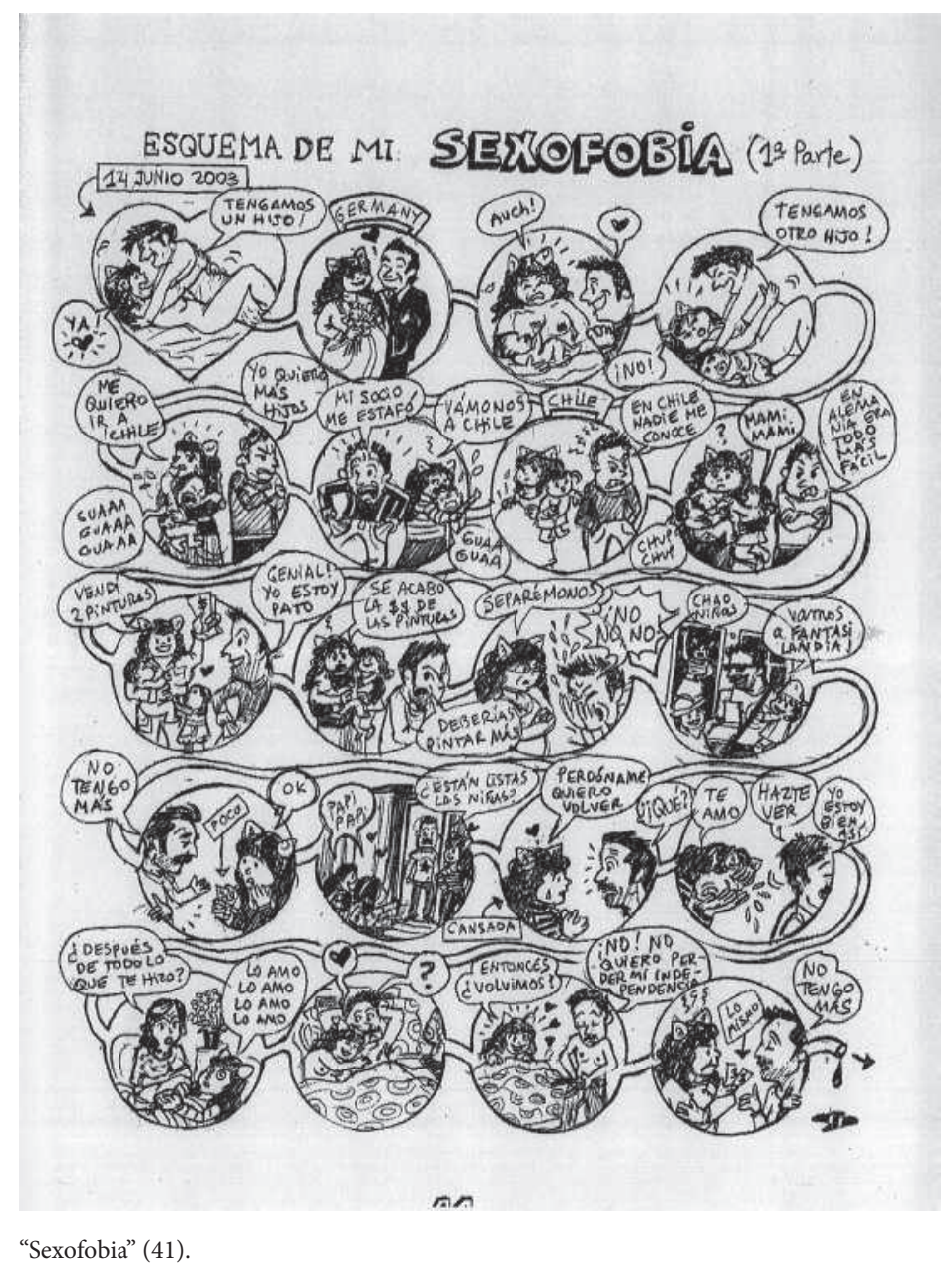

referencia a la ciencia ficción, que remite al mito de los orígenes), naves espaciales redondas o cascos de los astronautas flotando, cuya vestimenta está amarrada a un cordón que lo liga a la nave central.

Y conste que esta serie de círculos tiene como punto de arranque un corazón (donde se confunden sexo, matrimonio y maternidad), del cual se desprende una historia que se desenvuelve cual feto flotando en el líquido amniótico y algo enredado en el cordón umbilical. En fin, son las historias de amor que nos remiten a nuestros orígenes remotos (¿el cuerpo semicabrío del futuro marido que conecta el corazón con la primera redondela?; ¿el cordón alartijado que nos conecta con la serpiente bíblica?). Como se ve, esta página puede leerse naturalmente como una cita cultural, donde se combinan y entrelazan muy diversos intertextos visuales y escriturales. 
FIGURA 4

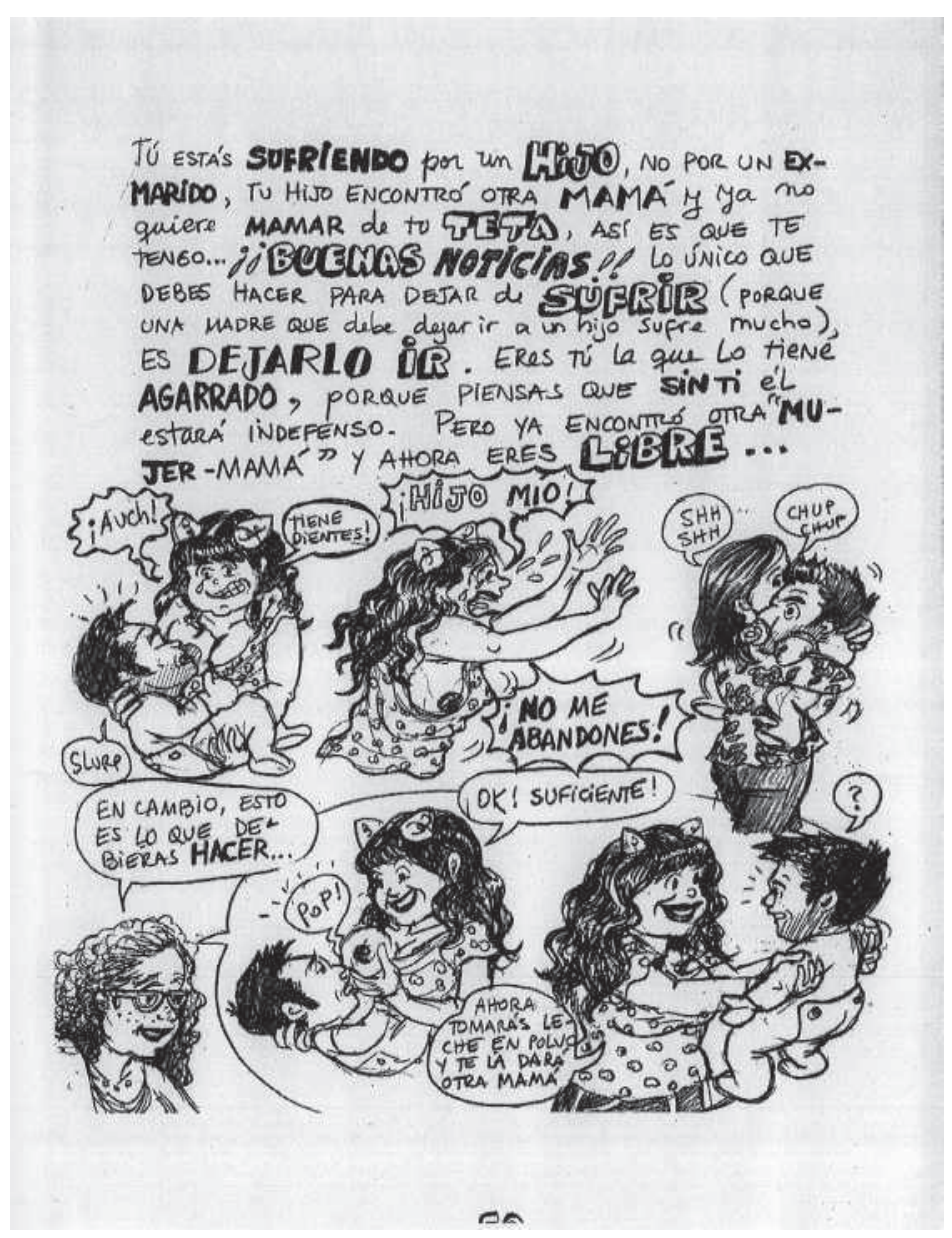

"La teta" (50).

Esta sección del hoyo negro, que inaugura el libro, continúa llenándose con la visita de la atribulada Maliki a distintas terapistas mujeres que le puedan ayudar a salir del impasse emocional. Así, desfilan ante nosotros la bruja (vidente), la numeróloga (adivina), la nutricionista-psicóloga y, por supuesto, la virgen La Dolorosa, quienes la instruyen, cada una a su manera, sobre cómo sobreponerse. Se actúa así un hilarante sicodrama, donde se exhiben los problemas de pareja, privilegiándose las miradas alternativas a la medicina oficial (siquiatra, sicólogo, sicoanalista) o presentándolas desde sus variantes informales, lo cual permite exhibir de modo más libre y transparente los estereotipos que nos rigen en el ámbito de las relaciones emocionales y de nuestras reacciones destempladas, así como de las posibles recetas para enmendar una natural y controvertida condición humana. 
Por supuesto, se le carga el peso a los hombres, lo que se ilustra, por ejemplo, con el síndrome del mamón (dispuesto en la fig. 4, que nosotros titulamos "La teta"). En esta página, a la escritura del diario, escrito con diversos tipos de letra que lo hacen intensamente sonoro y emocional -quien está siendo citada es la bruja buena-, le sigue su puesta en dibujo (su actuación en cómic), que tiene como singularidad la traducción literal de lo escrito. Este recurso a la confusión entre lo literal y lo figurado logra captar de modo grotescamente cómico un sentido reproche de las mujeres hacia el sexo opuesto y hacia sí mismas en la relación de pareja. Aquí la teta (el amamantamiento) articula la relación hombre-mujer, retornándonos de pasada a la serie de dibujos del llamado "Esquema de mi sexofobia", donde los personajes están englobados en círculos (es decir, en el complejo síquico de las tetas). No importa aquí tanto la crítica a este paradigma machista, sino especialmente el lenguaje en que se enuncia, que no deja a nadie fuera del cuadro, pues estos dibujos nos incluyen en ellos como sus dobles (así como lo es Maliki de Marcela).

Maliki sigue su recorrido para encontrar consuelo y acude a una iglesia que en su altar central tiene una pintura de La Dolorosa. Al quedarse mirando esta imagen, la virgen la saluda coloquialmente con una palabra encerrada en un globito ("Hola" 72) y le pregunta por los dolores de su corazón. El animado encuentro dura tres páginas. Realicemos un breve comentario de este teniendo presente la figura 5.

Lo primero que salta a la vista es la aguda flecha que nos señala el zoom de acercamiento al corazón de la virgen (dispuesto en un gran círculo), corazón que aparece tocado por un globito (una figura alargada, terminada en larga punta), donde la Dolorosa expresa su empatía con el dolor de Maliki (que se siente "abandonada", “engañada”), diciéndole: “...Pucha, lo siento mucho”. El diálogo es gracioso, porque pone en contacto dos discursos supuestamente paralelos: las penas terrenales de amor (separación, engaño, trama judicial) con las penas religiosas, que trascienden lo cotidiano; jugando a igualarlos. Indiquemos de paso que Maliki está dibujada como una niña; y aunque esta es la imagen común de nuestra protagonista, aquí se la exacerba -en la página anterior aparece entrando a la iglesia con un bolsón cruzado sobre el hombro, cual colegiala.

Estamos en el ámbito de la representación de la religiosidad popular transpuesta y animada singularmente en una historieta: la virgen bajando a tierra en su registro lingüístico ("Pucha"), su corazón dibujado a la manera de una baraja de naipes marcados o de un órgano animal goteando sangre en la carnicería -jugando con cierto arte barroco exagerado en una traducción kitsch-. Lo raro es que el corazón de esta virgen no es el suyo, sino el corazón de Jesús, que evoca el sufrimiento de toda la humanidad y que, incrustado en ella, nos asegura una benevolente reparación. En fin, podemos hablar coloquialmente de penas del corazón, que la Dolorosa entiende bien, todo lo cual permite la convergencia e hibridación de lo alto con lo bajo y lo sagrado con lo profano. Así se reinstala el sentimiento de religazón (re-ligare) de la persona con la divinidad en el ámbito de las relaciones comunes y corrientes. 
FIGURA 5

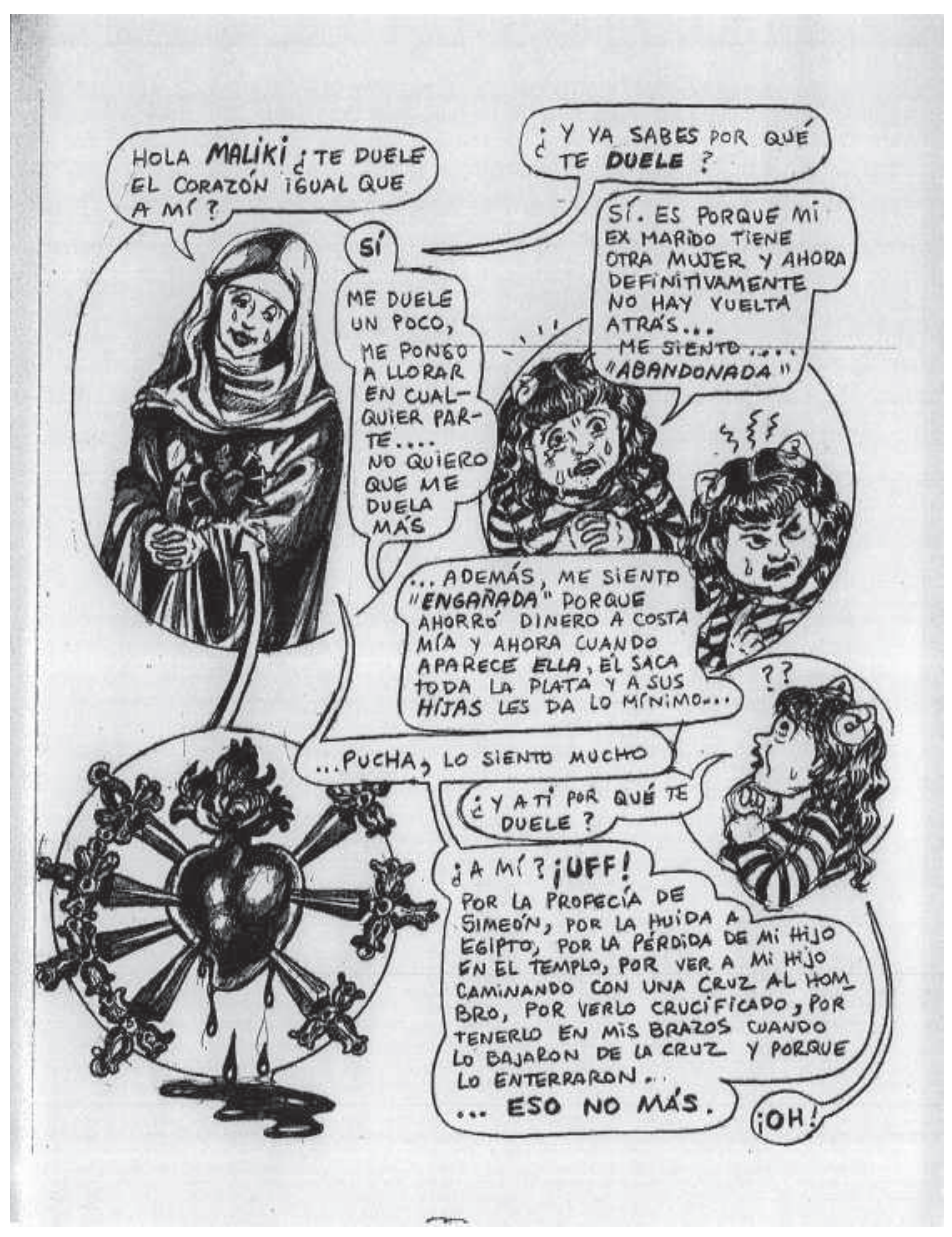

"La Dolorosa” (73).

Graciosa resulta también la connotación afectivo-infantil que se otorga a la escena. Los dibujos nos sitúan en regresión y así la virgen será el hada madrina, la madre a la cual volvemos para que nos abrace, como cuando niños (serán las imágenes de la página siguiente, 74).

La autora trabaja con figuraciones de la religiosidad popular, incorporándolas a su historieta de modo natural, con un dejo de malicia. Como se aprecia en la figura 6, a Maliki le gusta coleccionar imágenes de la virgen, que le sirven de amuleto (conversarán en las noches y al despertar, como se muestra en la página siguiente, 77). La virgen está situada, por lo demás, en la serie de amigas terapeutas, junto a la vidente, la adivina y la nutripsicóloga, en calidad de terapeuta espiritual. Conste que las imágenes en la tienda aparecen amontonadas, teniendo de seguro un precio barato. Y junto con 


\section{FIGURA 6}

Hasta que un BUEN die cerré mis ojos, como lo hacía siempre, reviví lo imá gen que me ayudabe a enfrentar mi. AWGOSTIO y mi RABDE y senté que los SOLTABA de mis manos y que CRRAD al VACOOO. Abrí los ojos y mo estoba LLORANDO. Volí' 2 dias mas y lo mismo: Mi pasuete de pañuelitos estabe intacto. Ahi decidi que era el momento de despedirme de La dolorosay dorle las GRasios.

Q la salida, a mano derecho, ectabe la FICTDDA de la Iglesia. Entré a pre guntar por una OMA $\mathrm{GE}$ (E) de mi mue

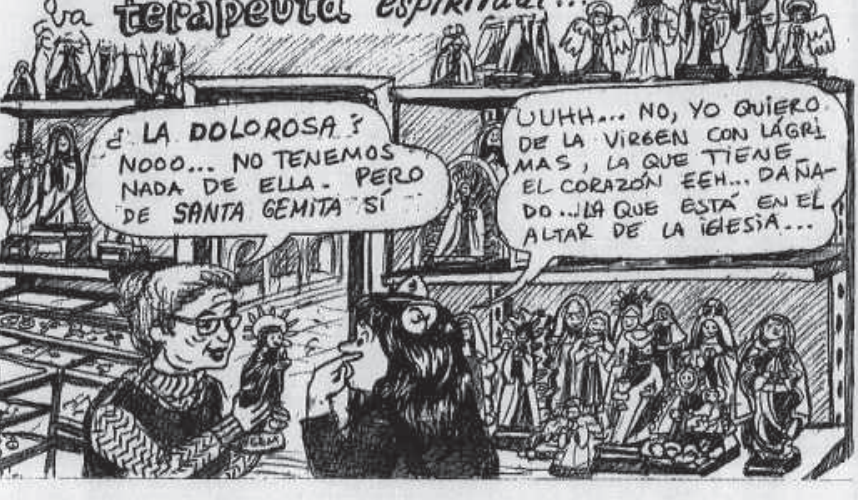

$\neg 2$

"Santa Gemita" (76).

incluir lo religioso en lo mercantil, la autora lo sitúa en el ámbito informal y bajo reglas semejantes a las de cualquier mercado: Maliki debe conformarse con Santa Gemita, pues parece que la Dolorosa no tiene tanta salida (demanda). Así, comprobamos que a la dibujante le entusiasma hacer bajar a la tierra tanto el arte culto como el mundo trascendente, cargándolo de lo real-concreto. La escenificación de lo religioso en lo cotidiano aparecerá siempre sustentado en un lenguaje coloquial, que hibridiza la sagrado y lo profano -en un globito de pensamiento, una Maliki dibujada como una niñita, antes de entrar a la iglesia donde se encontrará con la Dolorosa, piensa: "Dios Mío, Qué estoy haciendo aquí?" (72)-. 


\section{Autorrepresentación. Maliki con sobrepeso}

Si bien las escrituras autobiográficas tienen una imbricada relación con el referente, esto no las exime de una mediación subjetiva (la perspectiva singular del yo), generada desde la otredad del lenguaje. ${ }^{11}$ En el caso de este ejercicio, se agrega la conciencia autorial de producir un artefacto que juegue lúdicamente con las reglas adscritas al género de la autorrepresentación. En efecto, no se escribe tanto un diario, sino que se ensaya un cómic como si fuera un diario y más aún, un diario íntimo, que se supondría no debería leerse o que no está diseñado estrictamente para un público masivo.

En cuanto a la protagonista de esta historieta, Marcela Trujillo ha dibujado a Maliki, que no es estrictamente ella, sino una posible representación, interferida por el lenguaje paródico, que señala una clara distancia de la creadora con su creación. Como ya hemos hecho notar, Maliki tiene unas ampolletitas en su cabeza (poderes lumínicos, que evocan la ampolleta de los cómics usada para señalar una idea genial del personaje) y comúnmente es dibujada como niña, lo cual genera una tensión temporal y sitúa al lector en una situación de regresión: estamos en un presente adulto que incluye y rescata el pasado infantil. Por cierto, esta fricción y superposición de tiempos transforma un pequeño drama personal (por ejemplo, ser abandonada por su pareja) en un hilarante sicodrama que abre la lectura a variadas interpretaciones, amén de inocularnos en calidad de lectores con un gen regresivo.

No olvidemos, además, que la personaje es denominada Maliki 4 ojos y, sin embargo, nunca aparece con anteojos, salvo en la página que inaugura el diario después de la introducción, donde aparece el autorretrato de la autora, dibujada con los rasgos de una cuarentona (incluso algo exacerbados), escribiendo el libro recostada en su cama, armada de lápiz y goma y con anteojos, necesarios para bien dibujar (fig. 7).

¿Quién es ella? No es estrictamente la Maliki dibujada en el resto del libro, sino la autora dibujándose a sí misma como personaje (nótese los estampados de su camisa: labios que dicen "Kiss $m e$ ”, que dan señas de su espíritu lúdico y desinhibido). Aunque en verdad es un personaje en transición, pues lleva las ampolletas puestas: la Maliki saliendo de la cabeza de Marcela. ${ }^{12}$ Por ello, también puede plantearse que Maliki es concebida desde una dinámica del doble.

11 Para un panorama sobre las relaciones entre el yo y el lenguaje en el ámbito autobiográfico, remitimos al trabajo de Paul Eakin. Aquí se contrastan diversas posiciones, en especial la de Paul de Man con la de James Olney. Como es sabido, De Man propone que el yo no es la causa del lenguaje, sino su efecto más profundo, postulando entones que la base referencial de la autobiografía es una ilusión producida por la estructura retórica del lenguaje (en este caso particular, la prosopopeya). Por su parte, Olney considera que el yo es generado desde las metáforas que crea y proyecta; así, el yo y el lenguaje aparecen imbricados en un único sistema de comportamiento simbólico. Eakin suscribe esta última posición.

12 En el prólogo al libro El Diario iluminado de Maliki 4 ojos (2013), la escritora Lina Meruane despeja el carácter artístico (ficcional) que realiza la autora, que juega con un ilusionismo deliberado: "Trujillo sí ha escrito un diario: el diario de su pintoresco personaje. Lo más delicado de este trabajo seudoconfesional ha sido el procedimiento creativo de la autoconfiguración: la invención de un heterónimo - una autora ficticia aunque dentro del texto- que conquistara, en el largo tiempo de la obra, una voluntad que excediera la de la propia Trujillo. Y la autora lo consigue: este diario es entonces la reconstrucción ilustrada de una vida mediada por un alter ego malikoso y caricaturesco que viene a sumarse a otros dobles de Trujillo [Trukillo, Truki, Truka, usados en otros dibujos y pinturas], encontrables y hasta coleccionables es su ya dilatada trayectoria" (6). 


\section{FIGURA 7}

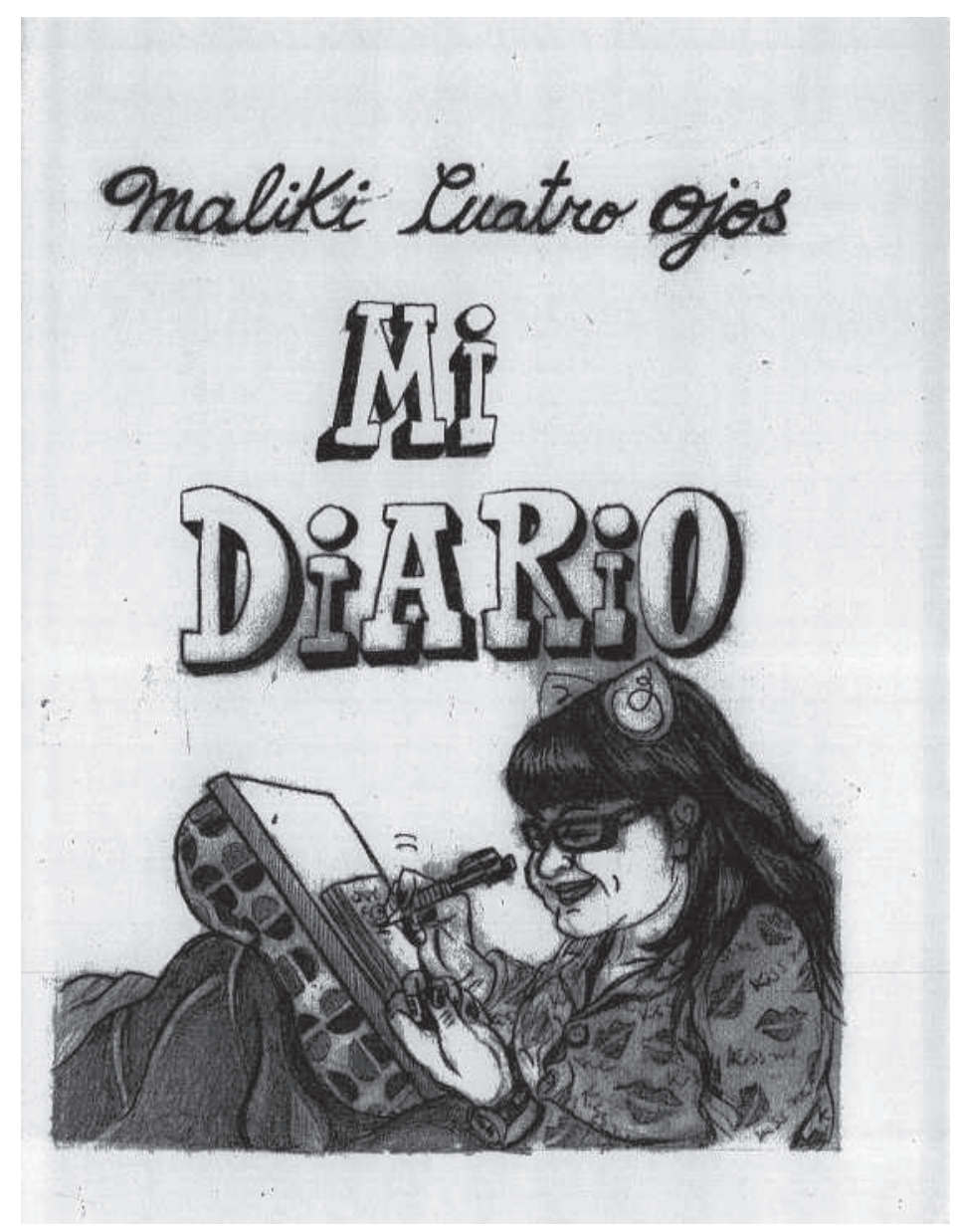

"Mi diario".

En este libro es notable la autoexposición del yo, desplegado siempre en el espacio público. Así, el libro comienza con la celebración del lanzamiento reciente de un libro anterior (Las crónicas de Maliki 4 ojos), con la autora -dibujada como Maliki-rodeada de sus fans (fig. 8) y justo en el mes de su cumpleaños. Es la alegre celebración de la autora -definida como alguien que dibuja y publica cómics-, que incluye la instancia de celebración pública del mismo libro que comenzamos a leer -el yo colocado en vitrina-. Se podría hablar de una selfie, una foto de un dibujo de sí misma. Sin embargo, debemos agregar que es una selfie que incluye un colectivo; en este caso, un grupo de personas ligado al arte gráfico, en su mayoría mujeres que pertenecen por edad a una misma generación. Por ello, aunque es un yo saturado de sí mismo, se inserta en una comunidad que tiene intereses y problemas análogos, como por ejemplo: ser 
FIGURA 8

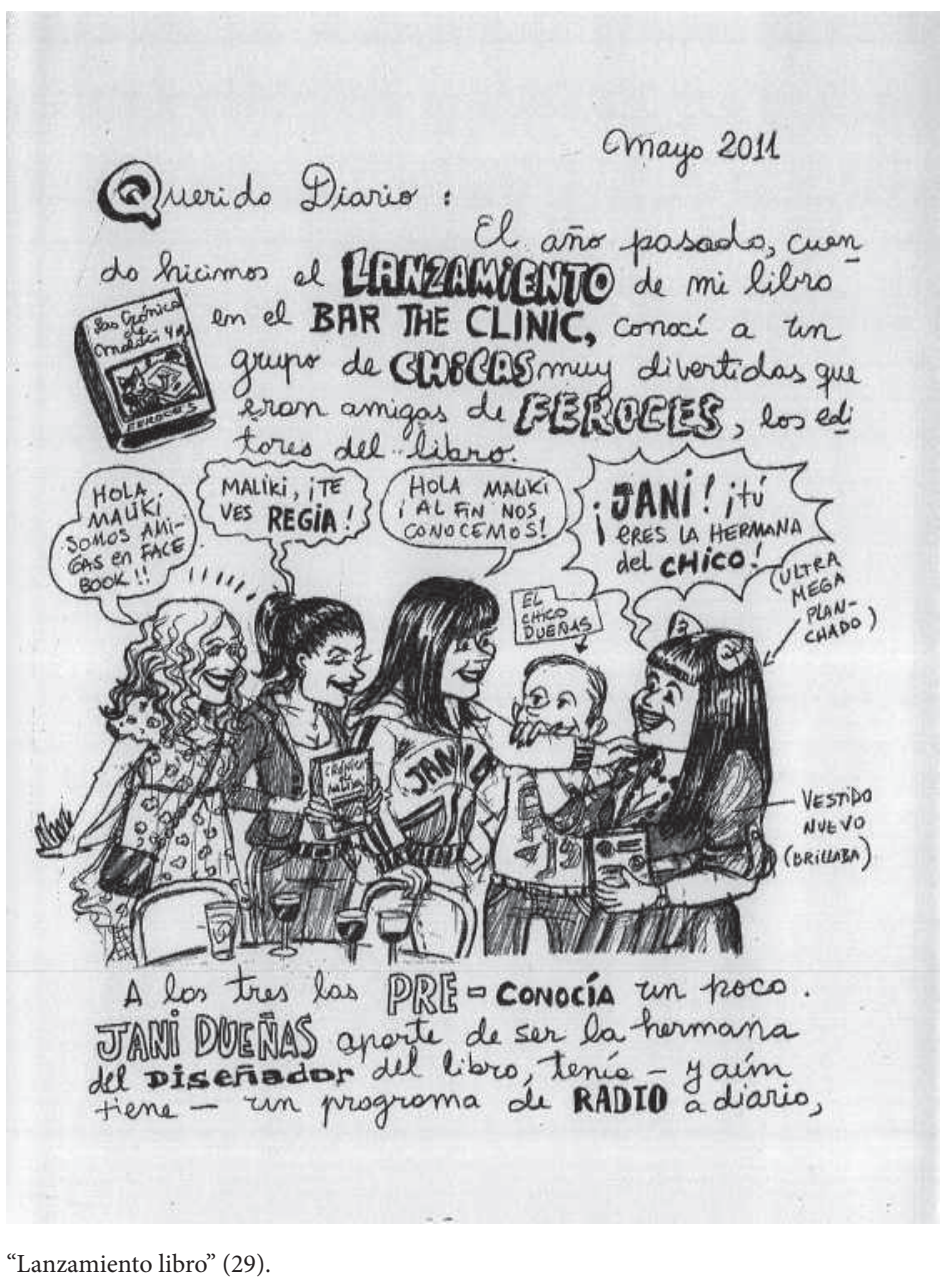

separada, autoemprendedora, hacer arte, criar, hacer dieta, entender a los hombres y sacarles trote o, como dice Maliki, llevarlos en la noche a la casa como trofeos (107).

Quiero referirme ahora a la autoexposición del cuerpo del yo, fijado en la gordura. ¿Cómo dibujarlo? Maliki aparece en paños menores, como un supuesto antimodelo de la perfección física femenina, bajo el rótulo MALIKI CERo (fig. 9). Quizás sea esta figuración uno de los aspectos más transgresivos del texto, por cuanto desnuda una preocupación (un complejo: ser gorda) y, simultáneamente, pone en tensión el paradigma de belleza normativo, sostenido por la publicidad, la moda y una variopinta gama de discursos culturales.

Describamos rápidamente esta página dedicada a Maliki Cero. Según leemos en el Diario (“Cuando me miro al EsPejo desnuda..."), en el dibujo Maliki está en el 


\section{FIGURA 9}

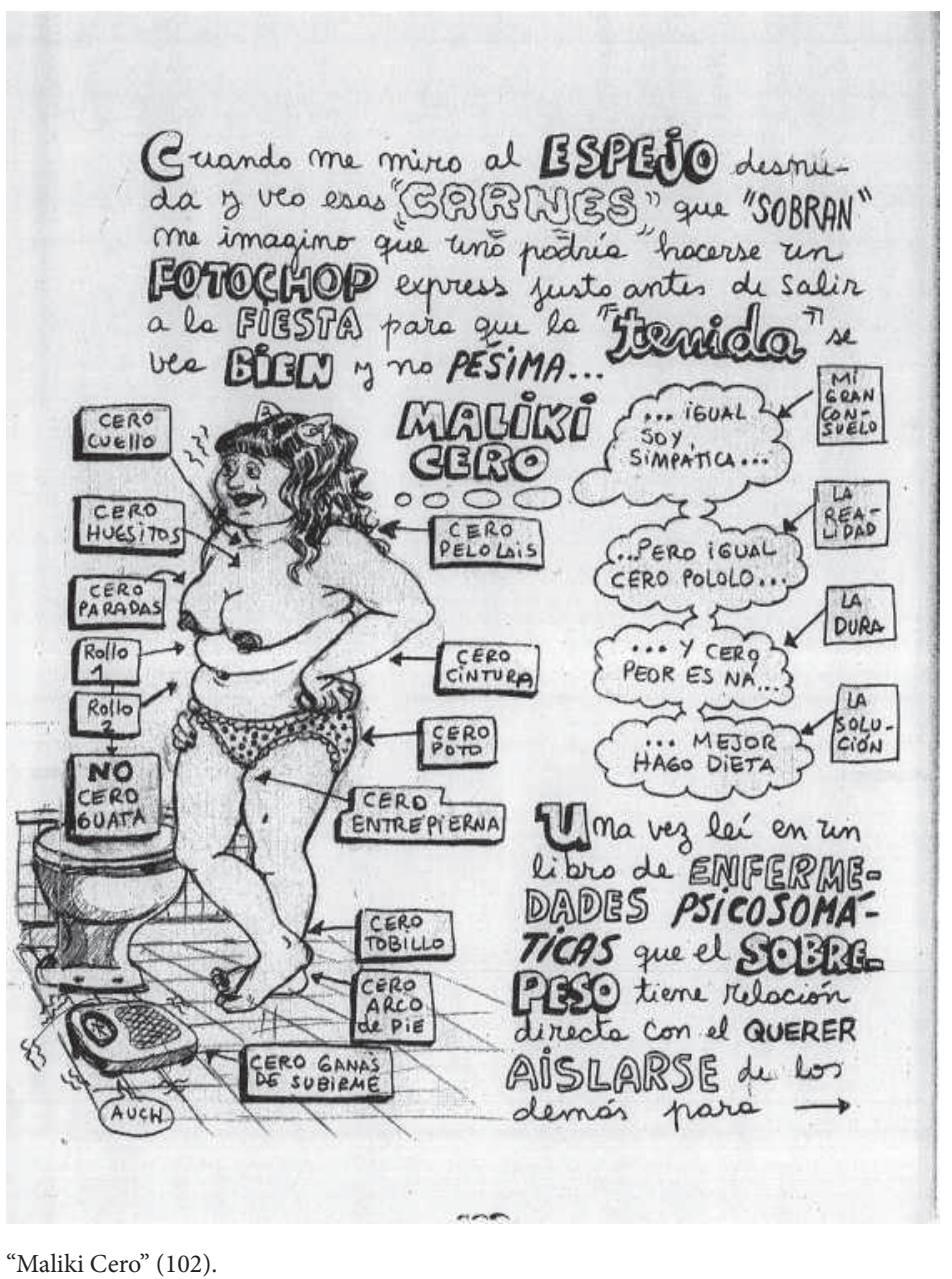

baño frente a un espejo que aparece fuera de página (fuera de escena) o constituyendo su límite izquierdo. Nuestra personaje aparece en pose (nótese el gracioso rebuscamiento de la flexión de su brazo izquierdo y la plasticidad en la posición de sus pies), solo con calzones con pintitas (que contrastan con el blanco del cuerpo, rimando con los pezones) y con su cintillo de ampolletas diablillas, ${ }^{13}$ dispuestas en medio de un peinado descuidado con chasquillas (aquí nos guiamos por el comentario de la autoría: "Cero pelolais"). Ahora bien, Maliki se dibuja con una expresión más bien ambigua: de azoramiento (marcado por tres pequeñas líneas eléctricas a la altura de

13 El Diccionario de uso del español de Chile (2010) define "peloláis" como: "mujer joven de clase alta o media alta, de apariencia muy cuidada, caracterizada esencialmente por el pelo largo y liso y el uso de ropa a la moda” (687). 
sus ojos), pero también satisfacción respecto a lo que ella ve (a pesar de todo), lo cual está en consonancia con su pose femenina y juvenil. ¿Una sonrisa y mirada pícaras a su doble en el espejo?

Este dibujo en cuerpo de Maliki, corrido un poco a la izquierda, pero siendo el centro de atención de la página (dibujo que se repite en el espejo, página ciega) viene comentado, primero, por una serie de cartelitos dispuestos en línea vertical a modo de pósits pegados en la croquera, que evalúan cada parte del cuerpo de modo negativo. Aquí el cero (redondo) equivale a nadie; evocando naturalmente el cero a la izquierda (que no vale), a la nota cero en cualquier evaluación (sin siquiera punto base); además de citar, por contrate, la bebida Zero, que Maliki acostumbra llevar junto a sus útiles de dibujo, para mantenerse en forma. Y luego, corrido más hacia la derecha, se alinea también en vertical una serie de nubes interconectadas con los pensamientos de Maliki, que son despejados por etiquetas, que nuevamente enuncian un principio de realidad.

La relación entre el dibujo, los pequeños rectángulos, los globitos de pensamiento y las series de letras que conforman la escritura del diario es muy dinámica, lo que establece variadas combinaciones. Indiquemos, a modo de ejemplo, la siguiente homología: el dibujo del cuerpo es a las etiquetas que lo circundan ("Cero cintura", "Cero poto"), así como sus pensamientos (que vienen de la sonrisa y los ojos) son a las etiquetas que la desambiguan de modo pleno ("La dura" "La solución"). En cuanto a las reflexiones del diario, las palabras con su especial diseño (“'CARNEs' que 'SOBRAN”) colorean, rellenan el cuerpo del dibujo y lo complementan lingüísticamente. Y resulta cautivante que Maliki imagine otro cuerpo, mediante la operación creativa del “FОтоснор”, como si estuviera examinando artísticamente su dibujo, con sus posibles variantes.

Hemos realizado una somera descripción de esta página titulada MALIKI CERO, poniendo énfasis en sus enunciados más evidentes. Ahora bien, en su enunciación esta página es también una celebración grotesca festiva de un cuerpo pleno. Es un dibujo que parodia los modelos de la proporción, que nos indican que la cabeza es un séptimo del cuerpo; una página cuyo dibujo evoca por contraste las láminas anatómicas con tristes esqueletos y con pequeños carteles indicando nombres de huesos y vértebras. En fin, una página empática, situada tanto en el eje personal como en un eje comunitario (el grupo de mujeres que viven aproblemadas con su sobrepeso, preocupación igualmente extensible a los hombres), que invita a reflexionar con humor sobre nuestros complejos corporales y los discursos sociales asociados a ellos. Cómic autoparódico, que también puede llegar a funcionar como una lectura de ayuda, en tanto menciona en tono cómico palabras prohibidas o eufemísticas: personas gorditas, la grasa como aislante, hacernos sufrir (103), aprender a quererse frente al espejo y de paso hacerse cargo de las explicaciones sicológicas que contextualizan la situación. ${ }^{14}$

14 Nos atenemos aquí a la noción de parodia de Mikhail Bakhtin, propuesta en su Problems of Dostoevsky's Poetics. Hay parodia cuando el autor introduce en el discurso de un personaje una intención semántica que le es opuesta, por lo cual el discurso es concebido desde el enfrentamiento de dos voces divergentes. Especificando más esta noción, Bakhtin indica: "Parodistic discourse can be extremely diverse. One can parody another person's style, one can 


\section{Maliki y sus amigas. El placer de dibujar}

Maliki tiene muchas actividades solo con sus amigas, como por ejemplo, y aquí citamos una de las listas animadas de este cómic, ir a bailar, echar la talla, celebrar (cumpliendo cuarenta años), copuchar, al cine, a fiestas muy choras y a inauguraciones y lanzamientos de sus propias producciones, donde se han apoyado y han trabajado juntas en distintas instancias (118-19), además de los regalos que se intercambian y de los vestidos que eligen con la aprobación de las entendidas (110-18).

Existe un claro registro generacional, donde la situación de Maliki -separada con hijos, instaurando juicio para obtener la pensión alimenticia, trabajando generalmente por cuenta propia, en constantes emprendimientos y, en este diario, buscando la felicidad, es decir, una nueva pareja- puede ser replicada en el colectivo de mujeres. Nos enteramos de sus preocupaciones, su independencia sexual, sus códigos de solidaridad, sus formas de expresión del relato cotidiano. Indiquemos de paso que todas sus amigas aparecen con sus nombres y reconocibles desde sus retratos: son tratadas con afecto y simpatía. En el caso de los hombres, reciben un trato disímil, más bien paródico, y le toca al exmarido un trato especial -como se dice coloquialmente, se le hace carinito-.

Un aparte para comentar la tensión entre lo privado y lo público en el ámbito de los nombres propios. ¿Se estará violando la privacidad de todos los nombrados? ¿Se les habrá pedido permiso a todos ellos? Sabemos que algunos se enfurecieron (el ex); otros han pedido no ser nombrados y esto se ha respetado; e incluso otros exigen aparecer en el libro, pero con su mejor perfil. Considero que en los dibujos de toda la ralea de personajes, más que exhibirse una intimidad personal, se exhiben ciertos tipos sicosociales, encarnados casualmente en ciertos trazos, parlamentos y anotaciones (gestos, giros lingüísticos, formatos variados de dibujos); se trata así un sentimiento generacional, desde un discurso en apariencia sin filtro sobre el comportamiento humano. ${ }^{15}$

De este modo, la fachada histriónicamente realista está sustentada en el placer del juego artístico, en el ánimo lúdico que tergiversa lo real y produce un constante engaño a los ojos (como en la tradición del relato clásico español). Esbozos del mundo en un cuaderno manufacturado que vemos siendo escrito y dibujado mientras leemos.

parody another's socially typical or individually characterological manner of seeing, thinking, and speaking. The depth of the parody may also vary: one can parody merely superficial verbal forms, but one can also parody the very deepest principles governing another's discourse" (194). En el caso de Marcela Trujillo, el gesto autoparódico incluye lúdicamente la ambivalencia.

15 Lúcidamente, Lina Meruane plantea que Maliki encarna varios estereotipos, en un juego autoparódico que le permite sostenerse en sus dos pies entre llantos y risas: "el de la Hija rebelde sin causa todavía conocida y el de la Hermana pataletera y envidiosa. El de la Esposa transformada en Divorciada Resentida. El de la Madre-Perfecta, toda bondad y el de la Madre-Monstruo, neurótica, gritona, destructiva. El de la Amante lujuriosa e insaciable. El de la Profesora-Sirvienta. El de la Adicta. ... En todas esas Maliki rigurosamente pasionales se vislumbra una lucha denodada ante la rigidez de los roles que les toca interpretar, rigidez que para ser remecida requiere ser puesta bajo la lupa implacable de la dibujante" (7). 
Verosímil, entonces, hiperrealista, que tanto nos acerca a lo real como nos extravía de este mediante trucos y desvíos: Marcela no es Maliki, sus amigas son en realidad actrices de una historieta, se fabrica un FINAL FELIZ, a través del encuentro con Marcelo, ilustrador gráfico, que permite una salida de escena triunfal de la protagonista -y aquí, qué rara coincidencia de nombres, más allá de que el referente supuestamente la avale: Marcela, Marcelo, Maliki-.

Junto a su atribulada vida sentimental (la caída en el hoyo negro y cómo va saliendo de allí) y a su entretenida y solidaria red de amigas, Maliki guarda un maravilloso bálsamo, que la devuelve a la imaginación lúdica infantil: el arte, el oficio de las artes plásticas. Este diario, además de exhibir con qué materiales y bajo qué reglas está compuesto, dedica un capítulo sobre un taller colectivo al cual Maliki es invitada por un grupo de artistas más jóvenes, el Gabinete de dibujo, que tiene como tema la cartografía: "un pie forzado para que los artistas comiencen a DIBUJAR, pintar, recortar, pegar, secar, hablar y pensar” (91).

\section{Familia, un mundo feliz. Familia y ciudadanía}

Además de ser artista y tener dos hijas entrañables, Maliki es muy familista: en la línea de las brujas-videntes-nutripsicólogas (más la Dolorosa), aparece la mamá, quien la reenvía a la genealogía materna desde los miedos e inseguridades heredadas -la confidencia ocurre frente a la televisión, mientras miran la teleserie de los años ochenta, que narra los miedos e incertidumbres de las familias chilenas en tiempos de dictadura-. En la línea de los libros, aparece el papá, de quien se hace una minibiografía: mantenía un diario de ideas y no tanto de anécdotas, escrito en libros de contabilidad (nótese la atención al contenido y tipo de formato), y ya cincuentón acude a talleres literarios (aparecen los retratos de algunos maestros, a modo de medallones) y se consagra escribiendo libros de cuentos (con diseños de portada de sus hijas). Ficha del perfil creativo del padre, realizado por la hija en un tono afectivo, con un sesgo paródico, propio de su estilo. Y en la línea de las hermandades, también aparece la ficha de sus dos queridas hermanas con sus familias. Además, aprendemos que en la actualidad Maliki, su hermana Polla y sus padres -todos emprendedores en diversos rubrosson vecinos (todos viviendo juntos, como cuando niños). La familia, un mundo feliz, congruente con el mundo del dibujo; ambos conformando acogimientos creativos.

Como se ve, Maliki tiene fuertes convicciones: sus dibujos, sus amistades (que giran en torno a su quehacer artístico y al privilegio del autoemprendimiento), su felicidad amorosa, el corro de las "mejores amigas" y su grupo familiar (padres, hermanas e hijas). No es, entonces, Maliki una mujer descreída, pues tiene fe en el amor, en la maternidad, en la familia y emprende la tarea de artista como un oficio deleitoso.

También la protagonista aparece ostentando el rol de ciudadana, en el ámbito de exponer una moral en la convivencia con el otro sexo (liberación sexual de la mujer), 
reconocerse como formando parte de la ronda femenina (solidaridad de género), practicar el arte como un oficio cotidiano más (diálogo deleitoso con las formas menores) y ser un testigo activo de su tiempo, en calidad de cronista gráfica. En este último aspecto, de un modo específico, nos referiremos a la documentación que realiza de las marchas estudiantiles para exigir una educación digna en Chile, realizadas en los mismos meses en que ella está haciendo este diario íntimo.

El texto le dedica un animado capítulo de diez páginas, denominado "Las marchas" (124-33), basado principalmente en el testimonio de sus sobrinos colegiales Simón y Amanda, dado en la casa de ellos; y también en las imágenes de las marchas que ella vio en la televisión y en su Facebook. Resaltemos de inmediato que las marchas aparecen aquí presentadas desde la experiencia de los mismos actores (los estudiantes) y sus relatos son escuchados en la casa, espacio afectivo de acogimiento. En consonancia con el hecho de que el movimiento estudiantil contara con el respaldo de las familias (los padres son los que sufren el alto costo de las matrículas), aquí es el seno familiar el que constituye la mediación por la cual la sociedad es vista y analizada. Como la gallina con sus pollos, la tía acude a la casa de sus sobrinos para saber de primeras aguas no solo qué ocurrió, sino también si han salvado ilesos. La razón es la propia experiencia de las marchas de protesta de los años ochenta, en plena dictadura, en que participó la muchacha Maliki e incluso fue detenida, por no ser rápida en su escapada de la fuerza policial -"mi estado físico siempre ha sido desastroso" (125). Así, este capítulo se esmera en generar un contexto sociohistórico (hay constantes alusiones a la historia reciente: los cacerolazos, la serie televisiva chilena titulada Los ochenta y, por cierto, las manifestaciones estudiantiles), además de un registro gráfico del presente.

Describamos brevemente una de estas páginas. La figura 10 presenta un abigarrado cuadro donde convergen de modo simultáneo diversas imágenes de las marchas. En un aparte, arriba (casi fuera del cuadro, como voz en off), aparece Simón dando su impresión de los eventos ("Era LO MÁxıMo, todos cantaban, bailaban, había distintos grupos, cantos, personas disfrazadas, esculturas gigantes, era INCREíBle, BACÁN...”). Y abajo, en un circulito, la niña Maliki realizando un comentario sobre la descripción del sobrino, (“iWOW!, SUPER CREATIVOs”), marcando así el carácter carnavalesco de los sucesos, que ponen patas para arriba el orden estatuido; lo cual ella transpone en dibujos para nosotros. ${ }^{16}$

16 Atraemos aquí la noción de carnaval propuesta por Mikhail Bakhtin para ciertas festividades del Mundo Antiguo y del Medioevo, donde se celebraba la vida asimilándola a un proceso material y corporal de cambio y renovación. Máscaras, risas, excesos corporales y lenguajes desusados, relativizan jerarquías y roles, permitiendo el libre flujo del bios. Los dibujos de las marchas estudiantiles evocan el espíritu grotesco festivo del carnaval bakhtiniano, tanto por la connotación de su lenguaje ("BACÁN", cita del desborde báquico), como por sus llorones monigotes y máscaras farsescas que deforman a las autoridades, y sus pancartas que dan vuelta el estado de cosas actual. Para una presentación sobre el carnaval y el grotesco festivo, remitimos al capítulo introductorio de M. Bakhtin, Rabelais and his World. 
FIGURA 10

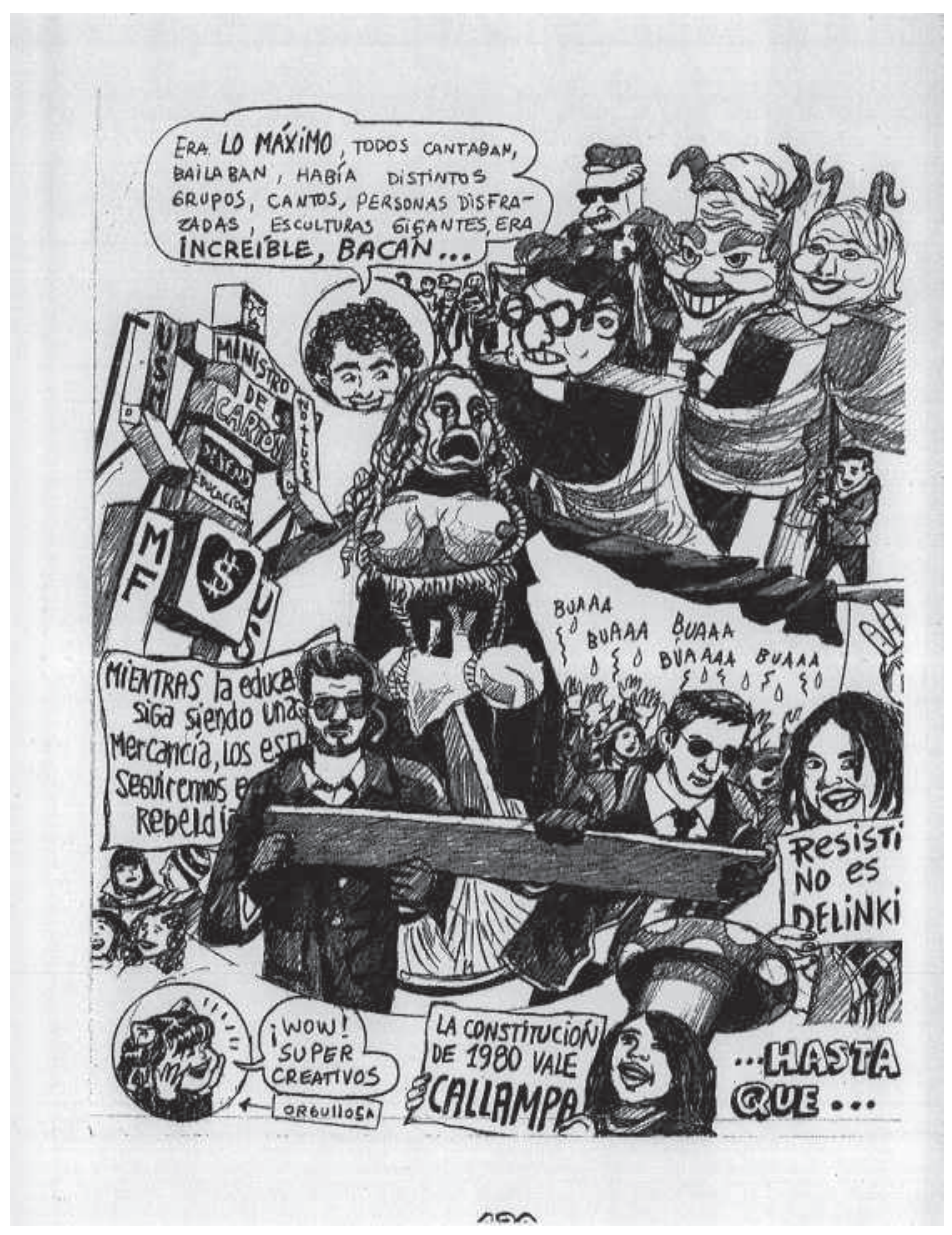

"Las marchas: Bacán” (130).

Un carnaval, un acto donde arte y vida se confunden, donde la caricatura y los modos artesanales de hacer objetos toman protagonismo, en que se confunden las imágenes de la calle con las mismas imágenes que pueblan los cómics. Volviendo a la página, señalemos que se abre a varios planos desde el dibujo de una grotesca escultura gigante, cuyos brazos de palo extendidos cortan en semidiagonal la página, lo cual permite que hacia la izquierda del dibujo irrumpa en otro plano un desfile de máscaras con expresiones burlonas o inamistosas; y hacia la derecha, un robot hecho con cartones rellenos con palabras y logos. Las delgadas maderas de los brazos pueden extenderse hasta el maderamen horizontal que soporta la escultura, formando un triángulo que aparece atravesado en su mitad por un madero vertical, que completa el soporte transportado por dos adultos jóvenes, también disfrazados y actuando (nótese el detalle de las gafas). 
Vemos en movimiento a una grotesca imagen funeraria de una madre dispuesta a amamantar a sus hijos a como dé lugar (sus tetas apuntan como cañones de acero), mientras que una criatura de trapo cuelga de su pelo y tirantes de una vestimenta de una sola pieza. Esta extravagante imagen, llevada en andas (que va caminando), aparece delimitada en su parte inferior por un semicírculo que llega hasta sus brazos, que distingue en su interior espacios en blanco que serán llenados por un cartel con un eslogan extenso (en parte tapado, pero que puede completarse sin problemas) y por el desfile de grupos de estudiantes (caras y manos en alto, gritos: "buaaa, buaaa”). En los límites del semicírculo (figura geométrica que juega a abrir y cerrar la vestimenta superpuesta de la macabra imagen, sustentada en el folklore popular), aparecen dibujos de muchachas con eslóganes - una de ellas sostiene un cartel que dice "La Constitución de 1980 vale CALLAMPA", con el sombrero correspondiente- y pequeños retratos de un grupo, que aparecen como actores y espectadores. Nótese que sobre el grupo de máscaras agresivamente traviesas (que aluden a figuras políticas, fácilmente reconocibles por el lector chileno), sobre el brazo izquierdo de palo de la imagen llorosa, aparece en chiquitito alguien con un palo (que también puede ser un rifle), que alude a la coda violenta que acompaña las marchas.

En su conjunto, la página completa aparece como deformada e inarmónica, sustentándose en su sobreexposición. Paradójicamente, aunque no sabemos bien cómo avanza la escultura gigante (¿cuál es la función del tablón vertical que parece enterrarla o cortarla como con serrucho, redoblando así sus lágrimas?); sí sabemos que su especial disposición en la página abre otros espacios, permitiendo una lectura tabular, donde interactúan simultáneamente distintos planos y perspectivas de todo el dibujo. Citando nuevamente el comentario de Maliki sobre las marchas, que le representa un gran desafío para su representación ilustrada, “iWOW! SUPERCREATIVOs”.

A nivel intertextual, la escultura central nos remite al folclor, evocándonos la figura femenina de La Llorona, que solloza eternamente por haberse visto obligada a matar a su hijo; de allí el coro que la acompaña con un sonoro "buaaa, buaaa."17 Estando en carnaval, su alarido de espanto es contrarrestado por la sonrisa de Simón que describe la escena (“BACÁN"), contextualizando el mensaje: aquí todos desfilan en el carnaval de disfraces, apareciendo hasta la misma Llorona.

Y como se puede apreciar en la figura 11 (Las marchas. Dragón 132), los disfraces abarcan también el mundo de los videojuegos de Nintendo (Super Mario, junto a su hermano Luigi), los manga (Sailor Moon, personaje de una historieta japonesa, que acaso atrae al dragón), que irrumpen en el mundo de la calle, transformándose en referentes culturales vivos de varias generaciones de jóvenes; junto a imágenes antiguas ("ku-kux clan"). Aparece también una tremenda careta de un carabinero (disfraz de "Paco Malo"),

17 "El origen de la Llorona se remonta a las épocas de la Conquista. Variadas narraciones cuentan sobre la relación entre una mujer indígena y un hombre español, producto de la cual nació un hijo o hija que fue rechazado por la familia de la madre, quien se ve entonces obligada a darle muerte. Los relatos señalan, por lo general, que ahoga a su niño o niña en un río y luego solloza eternamente por el dolor que ello le causa" (Montecino 417). 
FIGURA 11

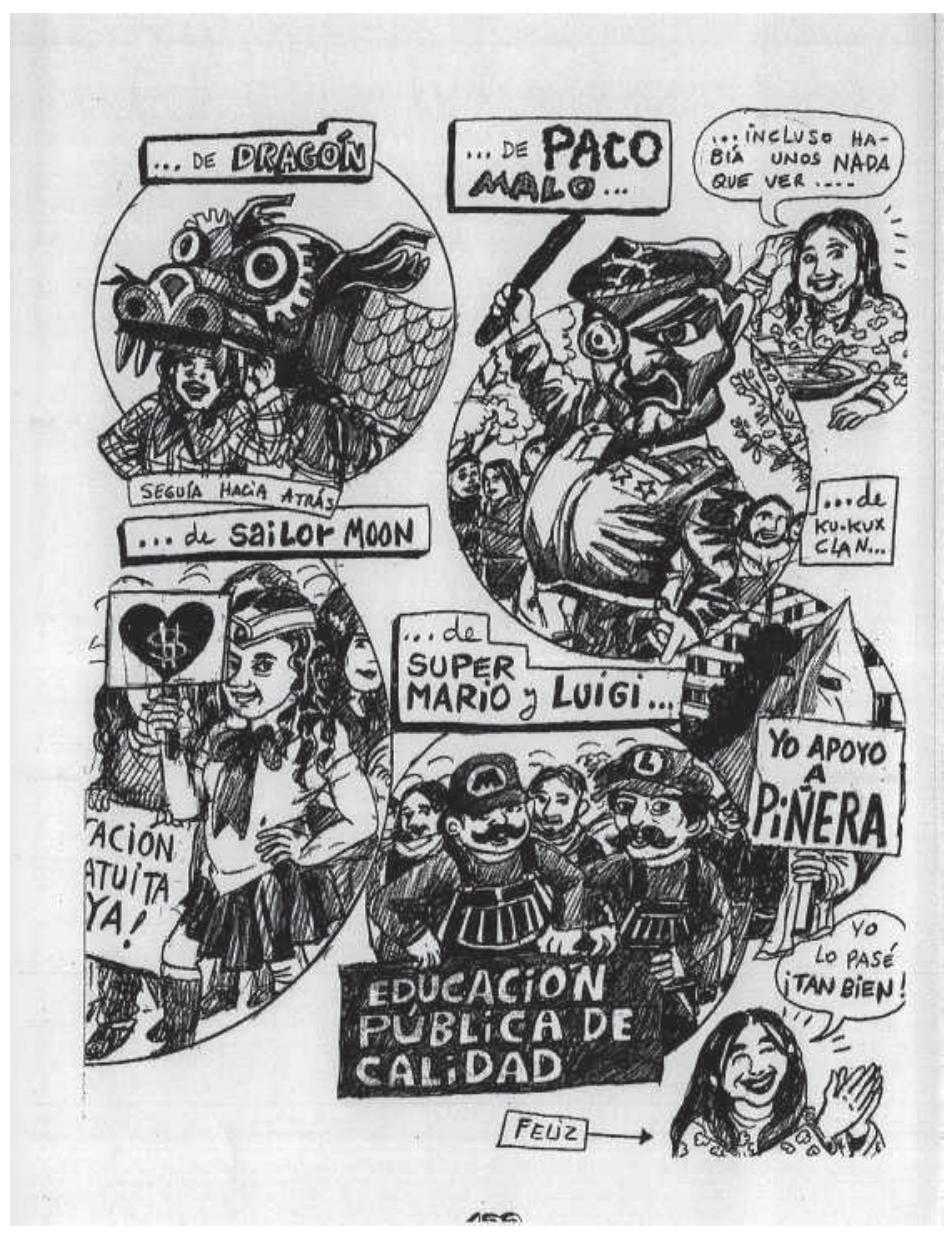

Las marchas: Dragón.

apodo que alude al "Pato Malo", nombre coloquial dado a los delincuentes y cuyo gorro lo emparenta con las sagas fílmicas o libros ilustrados (de aventuras) de los piratas feroces. Estos desfiles son, a su manera, un desfile de cómics, una celebración de caricaturas que tiene la virtud de generar nuevos espacios de libertad en la expresión humana. Así, es probable que, si hubiera nuevas marchas, de seguro hará alguien disfrazada de Maliki.

\section{Un aparte. Maliki y el género en disputa}

En este apartado final ensayaremos un breve comentario tentativo sobre este cómic, teniendo en cuenta la noción de género tal como ha sido enunciado por Judith Butler. 
Como ya lo hemos indicado, Marcela Trujillo actúa una escena conocida (casamientos, hijos, separación, sexofobia) y parodia los estereotipos socioculturales en los cuales estamos irremediablemente insertos. La pregunta que nos guía es la siguiente: ¿cuán subversivo es este gesto en el ámbito de las identidades de género?

Sucintamente, Butler plantea que el género no es una identidad preexistente ("natural"), sino que surge desde la performance que el cuerpo realiza a través de acciones reiteradas: "los actos, los gestos, los deseos organizados y realizados, crean la ilusión de un núcleo de género interior y organizador, ilusión preservada mediante el discurso con el propósito de regular la sexualidad dentro del marco obligatorio de la heterosexualidad reproductiva" (266-67). En otras palabras: "El efecto del género se crea por medio de la estilización del cuerpo y, por consiguiente, debe extenderse como la manera mundana en que los diferentes tipos de gestos, movimientos y estilos corporales crean la ilusión de un yo con género constante" (273-74). Desde esta postura feminista, la heterosexualidad se revela como un sistema normativo cultural que inhibe, censura y desautoriza otros modos de constitución de identidad de género.

Desde una lectura literal de los diarios de Maliki, se podría indicar que este cómic se encuadra de modo natural dentro el binarismo, universalizando el sistema heterosexual. En efecto, no hay desvíos en relación a esa norma y, más aún, el personaje encarna los actos que ese sistema tiende a perpetuar en nuestra sociedad: una mujer se enamora (como una niña), al quedar embarazada se casa, tiene dos niñas que quiere entrañablemente, sufre mucho por la separación, no puede reemplazar al hombre de su vida y su tema favorito con sus amigas son los hombres, a quienes intenta seducir para ser premiada con el acto sexual. Por otro lado, está muy ligada a su familia (querendona de su papá, protectora de sus sobrinos) y vive en una casa vecina a ella.

Por supuesto, esa lectura es falsa, pues no toma en cuenta la enunciación discursiva (de carácter intermedial) de este personaje. A través de su personaje Maliki, Marcela Trujillo actúa paródicamente una serie de acciones rituales que identifican la vida cotidiana y emocional de muchas mujeres. Así, por ejemplo, en esta performance remitimos a la Figura 4, "Sexofobia"- es el hombre el que pide tener un hijo (y ella accede, casándose) y luego exige un segundo hijo (aceptado a mal atraer por Maliki); además, la madre sufre con la lactancia y se le ve siempre atareada con las hijas en brazo y luego explotada económicamente por su ex. La comicidad es desbordante: vemos a una mujer-niña llorando desconsoladamente y cayendo en un hoyo negro por su dependencia de una pareja masculina. En resumen, se exhibe de modo tragicómico la performance de género en el sistema instalado del binarismo.

Ahora bien, ¿cuán subversivo será este cómico sicodrama? Al respecto, citemos la interrogante que plantea Butler: “¿Y qué tipo de actuación de género efectuará y mostrará la naturaleza performativa del género en sí de forma que se desestabilicen las categorías naturalizadas de la identidad y el deseo?” (271). 
¿Basta el gesto malicioso incluido en la configuración de Maliki para desestabilizar la noción naturalizada de género? Consideramos que este cómic presenta los estereotipos de las conductas de las mujeres en sus relaciones heterosexuales, y tiene la virtud de enunciarse como una autoparodia al mostrar las inmensas dificultades de salirse de los roles impuestos por el binarismo, sustento del patriarcado.

¿Eso es todo? No. Pensamos que el dibujo que inclina la balanza hacia una mayor radicalidad es la exhibición de un cuerpo casi desnudo, que resiste todos los pensamientos autocensuradores de la protagonista en "Maliki Cero" (fig. 9): todas las etiquetas incluidas en esta figura que asedian ese cuerpo. La figuración de un cuerpo obeso de mujer -en cortocircuito con las imágenes publicitarias y de la pornografía-, expuesto simpáticamente (como si se adivinara que se pone ante nuestros ojos lo reprimido, lo querido, el centro negado de nuestro deseo), devuelve los derechos de la mujer sobre su persona, instalando el cuerpo como el único soporte válido de la existencia humana. En efecto, si como propone Butler, en los sistemas normativos el alma es un espacio articulador del cuerpo, que lo precede y define -"el alma es de lo que precisamente carece el cuerpo" (264)-; en este cómic se presenta a una sujeto mujer que no tiene alma, por cuanto su cuerpo habla por ella: su personaje es alguien que siempre vuelve a la escena de modo rotundo e hiperbólico, más allá de los ahogos de conciencia.

\section{A modo de conclusión}

En este artículo hemos procedido a presentar este cómic desde sus variadas enunciaciones gráficas. Hemos querido exhibir el amplio repertorio de temas y figuraciones de esta autografía, privilegiando cómo se genera el personaje de Maliki, alter ego de la autora, y cómo se articula su relato en los ámbitos del arte, la familia y la ciudadanía, poniéndose énfasis en la identidad de la mujer.

A nivel de la producción textual, subrayamos el carácter materialista que le imprime la autoría a su creación. En efecto, sabemos qué materiales se usaron (por ejemplo, el tipo de lápiz, la marca de la goma, la tablilla de madera como soporte), el proceso de edición (escaneo, pruebas de imprenta, portada) y la programación de la circulación y consumo del libro (se nos instala en el lanzamiento del cómic).

En cuanto a la representación de la mujer -según ficha de la portadilla, Maliki es: "mujer cuarentona, soltera, rellenita, morena, madre de dos niñitas, pintora, dibujante y profe santiaguina, que no logra bajar de peso, encontrar a su príncipe azul, ni ahorrar dinero" (s. p.)-, se realiza un hilarante sicodrama sobre las penas de amor de la autobiógrafa, al parodiarse los estereotipos culturales que definen las relaciones de las mujeres con los hombres en la cultura patriarcal. Lo interesante es que esta crítica se realiza desde la autoparodia y ridiculización de la misma protagonista, con lo que se señalán la inmensa dificultad que implica situarse fuera de la norma. 
Esta historieta se propone desde la mirada cómica y (dis)torsionada de una dibujante mujer. Desde esta perspectiva, se trastocan y carnavalizan las reglas que rigen los comportamientos en las relaciones heterosexuales. A nivel ideológico, consideramos que los discursos y dibujos que delinean el cuerpo de la mujer (Maliki con sobrepeso) señalan nuevas perspectivas culturales en el ámbito de la discusión sobre sexualidad y género.

Este diario íntimo es una autografía donde la autora Marcela Trujillo se configura como Maliki, reinventándose como personaje. Es un cómic que tiene la virtud de enseñarnos cómo se hace un cómic y, por ende, de educarnos como lectores. Finalmente, es una historieta sostenida tanto desde una voz individual de mujer como desde un ímpetu generacional femenino: un cómic que despliega el ejercicio creativo de una ciudadana chilena que dibuja en el siglo xxI.

\section{Referencias}

Amaro, Lorena. "Que les perdonen la vida: autobiografía y memorias en el campo literario chileno". Revista Chilena de Literatura, n 78, 2011, pp. 5-28.

Bakhtin, Mikhail. Problems of Dostoevsky's Poetics. Minneapolis, University of Minnesota, 1984.

---. Rabelais and his World. Bloomington, Indiana University Press, 1984.

Butler, Judith. El género en disputa. El feminismo y la subversión de la identidad. Buenos Aires, Paidós, 2018.

Diccionario de uso del español de Chile. "Peloláis”. Santiago, mN Editorial, 2010.

Eakin, Paul. "Autoinvención en la autobiografía: el momento del lenguaje”. La autobiografía y sus problemas teóricos. Estudios e investigación documental. Comp. Ángel Loureiro. Barcelona, Anthropos, 1991, pp. 79-93.

Gusdorf, Georges. "Condiciones y límites de la autobiografía”. La autobiografía y sus problemas teóricos. Estudios e investigación documental. Comp. Ángel Loureiro. Barcelona, Anthropos, 1991, pp. 9-17.

Kukkomen, Karin. Studying Comics and Graphic Novels. Oxford, John Wiley \& Sons, 2013.

Meruane, Lina. "Prólogo". El diario iluminado de Maliki 4 ojos. Marcela Trujillo. Santiago, Ocho libros, 2103, pp. 5-9.

Molloy, Sylvia. "Introducción". Acto de presencia. La escritura autobiográfica en Hispanoamérica. México, Colegio de México-Fondo de Cultura Económica, 1996, pp. 11-22.

Montecino, Sonia. Mito de Chile. Enciclopedia de seres, apariciones y encantos. Santiago, Catalonia, 2015.

Newcomb, Rain. (In)Between Word and Image: Reading Comics. Tesis para optar al grado de Master of Arts in English. Western Carolina University, 2011. 
Osorio, Ana Cecilia. Hacia una lectura semiótica de los recursos tipográficos en el cómic Mafalda. Tesina para optar al grado de Licenciada en Letras. Pontificia Universidad Católica de Chile, 1997.

Rose, Sonya. ¿Qué es historia de género?. Madrid, Alianza, 2012.

Sarlo, Beatriz. Tiempo pasado. Cultura de la memoria y giro subjetivo. Una discusión. Talca, Universidad de Talca, 2013.

Trujillo, Marcela. El Diario íntimo de Maliki 4 ojos. Santiago, RIL, 2011.

Trabado, José Manuel. "La novela gráfica en el laberinto de los formatos del cómic". La novela gráfica. Poéticas y modelos narrativos. Comp. José Manuel Trabado. Madrid, Arco/Libros, 2013, pp. 11-61.

Trujillo, Marcela. Las crónicas de Maliki 4 ojos. Santiago, Feroces Editores, 2010.

---. El diario iluminado de Maliki 4 ojos. Santiago, Ocho Libros, 2013.

---. Maliki con tinta china. Santiago, Ocho Libros, 2013.

Trujillo, Marcela y Karolina Lama. Quiero ser flaca y feliz. Santiago, Planeta, 2015.

Enviado: 13 enero 2017 Aceptado: 8 noviembre 2017 